\title{
THE IMPLICATIONS OF THE DIRECT ELECTIONS IN ISRAEL
}

\author{
YÜKSEL SEZGİN
}

\begin{abstract}
Like many immature and fledgling democracies Israel has suffered from the same disease, which causes instability, inefficiency, maladministration, corruption, bribery, extortion and anarchy. However, unlike other countries, Israel has invented its own medication to cure the ills of its democratic system. This unprecedented "magic remedy" provided Israel with the distinction of being the first democracy to a have direct election for its prime minister. This study is dedicated to the examination of this "untested remedy" and its side effects. As the paper shows, the direct elections have totally altered the form of government, party system, electoral campaigns, and the voting behaviours in the Jewish State. By allowing the split-ticket voting (i.e. the separate voting for prime minister and Knesset), the new system has contributed to the further fragmentation of Israeli party system, strengthening the ethno-sectarian and single-issue parties at the expense of larger and ideological ones. In addition, while it has modified the traditional inter and intra-party politics and traditional coalition formation procedures, it also starkly exposed the absence of checks and balances within the system.
\end{abstract}

\section{KEYWORDS}

Israel; Israeli Politics; Knesset; Likud; Labour; Ethno-sectarianism; Election Systems; Electoral Behaviour. 


\section{Introduction}

The system of direct elections for the prime minister has shattered the Israeli political structure and made Israel an "ungovernable" country. As the new electoral system quickly destroyed Netanyahu and Barak, now it is predicted that Sharon will soon share the same destiny with his predecessors and be torn down by this destructive system in a similar fashion. Since 1996, regardless of who has been in power, the negative implications of direct elections have persistently disabled the Israeli prime ministers to control their governments, caused them to lose their parliamentary majority and call early elections each time. As a result, while the electoral system has become enormously crucial in Israeli politics, the identity or personality of the prime minister ceased to be an important factor in terms of manageability of the country. Now, the prime minister is not more than someone who is to play a pre-designated role and be destroyed by the system. Hence, to understand the implications of the direct elections upon the Israeli politics, one must draw upon the elections that are simultaneously held both for the Knesset and the prime minister. Therefore, for that matter, I shall limit the scope of this paper to only 1996 and 1999 elections rather than the February 2001 elections, which only replaced the incumbent Prime Minister Barak with Sharon and did not change the composition of parliament at all.

Like many immature and fledgling democracies Israel has suffered from the same disease which causes instability, inefficiency, maladministration, corruption, bribery, extortion and anarchy. However, unlike other countries, Israel has invented its own medication to cure the ills of its democratic system. This unprecedented "magic remedy" provided Israel with the distinction of being the first democracy to a have direct election for its prime minister. This study is dedicated to the examination of this "untested remedy" and its side-effects. The primary aim over the course of this paper will be to denote the implications of this reform upon the various aspects of Israeli politics. However, it should be noted that considering this reform merely as a change in the electoral system would be a great mistake. As I shall examine 
below, the direct elections have totally altered the form of government, party system, electoral campaigns, and the voting behaviours in the Jewish State. By allowing the split-ticket voting (i.e. the separate voting for prime minister and Knesset), the new system has contributed to the further fragmentation of Israeli party system and simultaneously strengthening the ethno-sectarian and single-issue parties at the expense of larger and ideological ones. In addition, while it has modified the traditional inter and intraparty politics and traditional coalition formation procedures, it also starkly exposed the absence of checks and balances within the system.

\section{Diagnosis of the Malaise and the "Magic Remedy"}

Until 1977, the extremely fragmented, fractionalised and polarised nature of the Israeli party system was masked by the dominance of Mapai. ${ }^{1}$ However, since then, particularly during the 1980 s, this weakness of the system has led to difficulties not only in the formation of governments, but in their survival as well. ${ }^{2}$ Weak governments and frequent crises came to be perceived as extremely disruptive to the stability of Israel's democracy by both the electorate and the politicians. ${ }^{3}$ The ineffectiveness of the government's decision-making process, the long period of bargaining required to form coalitions, the proliferation of small parties with blackmail potential and the "stinky trick" experience of 1990 intensified the attempts for electoral reform. Hereafter, diagnosing the existing malaise of the Israeli political and electoral system, I shall take a closer look at the complaints raised by those who were supporting the electoral reform.

One of the motivations for electoral reform was the result of past tensions in the creation and survival of political coalitions:

\footnotetext{
${ }^{1}$ Originally, an acronym for Israel Workers' Party. Created in 1930, it was the dominant party in Israel until its merger in 1968 with Ahdut Haavoda and Rafi to form Israel Labour Party.

${ }^{2}$ V. Bogdanor, "Israel Debates Reform", Journal of Democracy, Vol. 4, No. 1, 1993, p. 69.

${ }^{3}$ R. Y. Hazan, "Executive-Legislative Relations In An Era of Accelerated Reform: Reshaping Government in Israel", Legislative Studies Quarterly, Vol. 22, No. 3, 1997, p. 331.
} 
This kind of situation gave disproportionate influence to small parties whose support could make the difference between a party capable of forming a government and one incapable of doing so. ${ }^{4}$ Since 1977, the developing close competition between Labour and Likud has commanded the support of roughly equal portions of the Israeli electorate. This has provided the smaller parties with considerable blackmail potential. ${ }^{5}$ With two competing parties seeking to form coalitions with the same smaller parties as necessary partners, logic of capitulation was set into motion. Playing one large party off against the other, the small parties were in a position to constantly up the ante by transforming the promises made by one side into baseline demands for negotiating with the other. In this way, the smaller partiesat times even individual members of Knesset used to extract staggering political prices from their larger counterparts. ${ }^{6}$ This rendered small parties and individual members far more powerful than their numbers in the electorate warrant. In the middle of the way by switching side, threatening to form a coalition with the opposing major party, elements representing a small minority could make outrages and extortionate demands. Thus, this created governments that habitually flouted the will of the majority. ${ }^{7}$ Broadly speaking, this meant subjugation of the majority's will and interest to those of the minority. ${ }^{8}$ Beyond this political price, this horse-trading had a financial cost as well. These tricky relations engendered tremendous waste of national sources due to horse-trading, briberies, private budget allocations to religious funds and seminaries (yeshivot). As a result, billions of shekels were annually handed out to small extortionist groups, particularly the religious ones. ${ }^{9}$

\footnotetext{
${ }^{4} \mathrm{G}$. Mahler, "The Forming of the Netanyahu Government: CoalitionFormation In A Quasi-Parliamentary Setting", Israel Affairs, Vol. 3, No. 3-4, 1997, p. 4.

5 Bogdanor, Israel Debates Reform, p. 69.

${ }^{6}$ B. Susser, "The Direct Election of the Prime Minister: A Balance Sheet", Israel Affairs, Vol. 4, No. 1, 1997, p. 239.

${ }^{7}$ Editorial, "Emasculated Reform", Jerusalem Post, 10 January 1992.

${ }^{8}$ U. Lynn, "Labour Supporters Turned Saboteurs", Jerusalem Post, 24 June 1994.

${ }^{9}$ C. Herzog, "Half Baked Reform", Jerusalem Post, 20 January 1995.
} 
The vulnerability of the government and the prime minister in particular to extortion of individual, sectarian, ethnic and parochial interest groups undermined the executive branch. The prime minister was unable to prevent the frequent cabinet crises brought on by inter-party and intra-party political manoeuvring. His authority vis-à-vis his ministers was limited and he himself was dependent on them for political support. Since each minister represented a party or faction within a party, the premier had to tolerate his ministers' blatant failures, destructive feuds and flagrant transgressions in silent frustration. Apparently, the prime minister was nothing more than a hostage held by small coalition partners.

David Libai, a Labour MK (Member of Knesset) and one of the initiators of reform process, summarised the existing situation as of May 1990, by following words:

Elections are held, and no one knows who will be prime minister. Not only because it is a matter for coalition negotiations, but because a situation has been created where parties, especially small ones, are the ones who decide. At times the decision is made not within the party but without, by an authority or a great rabbi. The whim of a single Knesset member can decide not only who will be the prime minister but also the fate of the people. ${ }^{10}$

In this respect, it may be claimed that the choice and composition of the government were practically out of the hands of the voters. This has basically shaken the confidence of the broad public in system of government and more dangerously in democracy. This situation was exacerbated by the National Unity experiences in the late 1980s and early 1990s. Actually, the inflated public desire for the replacement of this corrupt and unstable system was exploded by the spark of March-June 1990 crisis.

In talking about the National Unity Governments (19841988 and 1988-1990) one may say that after the elections for the $11^{\text {th }}$ Knesset, it became apparent that the National Unity Government had difficulties in functioning. Since it was composed of two parties with diametrically opposed outlooks and interests, members of the government wasted a great deal of energy and state

\footnotetext{
10Jerusalem Centre for Public Affairs, Direct Election of the Prime Minister, Changing the System of Government in Israel, Jerusalem, 1990, p. 43.
} 
resources in internal squabbles and rivalries that encumbered the efficient functioning of the government. ${ }^{11}$ The crisis that finally toppled the government was initiated by Labour against the Likud's intransigent position toward the peace process. The motion of noconfidence sponsored by RATZ ${ }^{12}$ was passed on 15 March 1990 by 60 votes to 55 and brought down the Likud-led second National Unity Government. This was the first time in history of the Israeli parliamentary system that a government was forced out of office by a no-confidence vote.

The "dirty exercise", a phrase coined by Yitzhak Rabin, was Shimon Peres's master plan to end the National Unity Government and then replace it with a coalition based on the Labour Party and one or more of the religious parties with himself as prime minister. After the President asked Peres to form and head a new government he started to use "every trick in the book" in order to persuade the pivotal Shas ${ }^{13}$ (as well as other religious parties) to participate in his government. ${ }^{14}$ Meanwhile, the Likud was busy trying to block Peres's attempt and prenegotiating its own government. Finally, Likud succeeded in forming a narrow coalition. Thus, the notorious filthy trick of Labour failed and brought about a major public outcry for the reform of the political system. As Larry Diamond and Ehud Sprinzak point out:

In fact, the three-month crisis was unprecedented in one sense: it starkly exposed the malfunctioning of the Israeli system of government and, more than ever before, made most Israelis aware of the problem. But almost everything that took place between March and June of 1990 had happened before: coalition horse-trading; political blackmail and extortion by small extremist parties; shamelessly open political bribery; blatant and obsessive partisanship by the nation's top policymakers; complete disregard for matters of national interest. What was special about the 1990 spring crisis was that it happened on a larger and more intense scale. The spiritual gurus of the ultra-orthodox partiesanti-Zionist rabbis in their eighties and

\footnotetext{
${ }^{11}$ Ibid., p. 5.

12RATZ (or RATS- Citizens Rights Movement): a left-wing party, founded and led by Shulamit Aloni. Currently, it is a component of Meretz.

${ }^{13}$ Shas: an ultra-orthodox party, split from Agudat Israel in 1984, and appeals to the Sephardim.

${ }^{14}$ A. Diskin and H. Diskin, "The Politics of Electoral Reform in Israel", International Political Science Review, Vol. 16, No. 1, 1995, p. 40.
} 
nineties were made the ultimate judges of Israel's national interest. Hundreds of millions of government dollars were readily committed as coalition bribery to tiny parties. Top ministerial and bureaucratic positions were offered to inexperienced and corrupt MKs in exchange for their votes. Several especially unscrupulous MKs used the opportunity to split from their mother parties, instantly tripling and quadrupling their price in political supermarket. ${ }^{15}$

This aborted and senseless process of turmoil into which the political system was thrown and the ugly horse-trading and political blackmail that accompanied it triggered the emergence of a protest movement in favour of changing the electoral and governmental systems. It involved hunger strikes, a petition signed by over half million citizens and a mass demonstration in Tel Aviv. ${ }^{16}$ According to a Gallup poll in May 1990, 89 per cent of the public was supporting the electoral reform. ${ }^{17}$ The result was an almost automatic inclination of politicians to support overtly "popular" proposals for reform, regardless of their content and consequences. This trend became more evident prior to general elections in 1992.

As a response, reform followed. In February 1991, the Knesset reacted to this unseemly chain of events by passing legislation intended to change basic parliamentary norms. According to new amendment (No: 12) to Basic Law: the Knesset, a MK who resigned from the party on whose list he or she was elected, or who voted against his or her party line in a confidence or no-confidence vote for the government would be penalised. The offending MK would not be recognised as a member of any other party grouping within the Knesset; would not be allowed to run in the next elections on a list represented in the current Knesset; would not be allowed to serve as a minister or deputy minister during the term of the Knesset in which the prohibited act occurred, and would not be entitled to party financing from the

${ }^{15}$ A. Brichta, "The New Premier-Parliamentary System in Israel", The Annals of the American Academy of Political and Social Science, Vol. 555, 1998, pp. 183-184.

${ }^{16} \mathrm{E}$. Bick, "Fragmentation and Realignment: The Triviality of Normality; the Significance of Electoral Power", in D. Elazar and S. Sandler (eds.), Israel at the Polls, 1992, Maryland, 1995, p. 295.

${ }^{17}$ Bogdanor, Israel Debates Reform, p. 90. 
public treasury. ${ }^{18}$ Another amendment also attempted to prevent the single-MK factions by increasing the threshold from one per cent to one-and-half per cent. ${ }^{19}$

Apart from these initial reforms, those who wanted a complete change in the system backed to an already existing reform proposal: direct popular election of the prime minister. Despite the fact that this reform proposal was submitted to the Knesset in the late 1980s, until the last government crisis and its aftermath it was not taken into consideration as a feasible solution. However, subsequently the adoption of the direct election for the chief executive was perceived as the linchpin that would make Israel get rid of its existing problems. In fact, it should be recorded here that the allegedly success story of the reform at municipal level in the form of direct elections of mayorshelped lead public opinion in this direction. ${ }^{20}$

Under this proposed reform, the prime minister would be elected directly by the people in balloting separate from, but concurrent with, the Knesset. A critical feature of this plan required that the successful candidate was to win an absolute majority of the vote, providing for a runoff election between the two leading candidates if none obtained a majority in the first round. Moreover, the most striking feature of the proposal was that the directly elected prime minister would not need the approval of the Knesset for the appointment of his ministers and it would require a

${ }^{18} \mathrm{~A}$. Arian, The Second Republic, Politics in Israel, New Jersey, Chatham House, 1998, p. 203.

${ }^{19}$ U. Lynn, "We Don"t Need More Reform", Jerusalem Post, 15 April 1992.

${ }^{20} \mathrm{R}$. Gideon, The Politics of Reform in Israel: How The Israeli Mixed System Came to Be, unpublished paper, Jerusalem, 1999, p. 10. Since 1978 , mayors have been directly elected by the voters on a ballot separate from the party list vote for city council. However, as a result, the local branches of both the Likud and Labour have become weaker. In discussion of the issue, Prof. Diskin draws attention to split voting and proliferation of small parties within the city councils. Assessing the results of the first election held under the new Basic Law: The Government in 1996, he postulates that anyone who kept an eye on what was happening on a municipal level knew in advance that this system was going to ruin the two large parties on national level as well, A.K. Sommer, "Local Issues vs. Party Loyalty", Jerusalem Post, 30 November 1998. 
qualified majority (70 out of $120 \mathrm{MKs}$ ) within the Knesset to pass a no-confidence vote in the prime minister.

Supporters of this reform argued that direct election of a prime minister would award electoral choice to the voter. The elector would be able to choose his prime minister rather than find a prime minister chosen for him after prolonged coalitional negotiations. The citizen would know who was to be prime minister on the morning following the election. Therefore, potential partners would have to co-operate with the directly elected prime minister, because there would be no way of changing the candidate for prime minister short of new elections. In other words, the prime minister, independent of "blackmailing influence of smaller parties" and individual MKs, would be able to run his government as a stable and cohesive body. ${ }^{21}$ As asserted by the reformers, this did not necessarily mean that direct elections would eliminate coalition bargaining altogether. However, according to their assertion, it would alter the whole context of coalition formation. Since it is immediately clear who will be forming the government, the entire logic of capitulation would be avoided. ${ }^{22}$ Negotiations would be held either before the elections as the small parties publicly throw in their lot with one candidate or another and thus identify themselves with that candidate's platform, or after government has already been formed (since the prime minister would no longer need the approval of the Knesset for his government). ${ }^{23}$

The proponents of the reform suggested that direct election of the prime minister would also strengthen the incipient bipolarity and reduce the level of fractionalisation in the Israeli party system. ${ }^{24}$ This supposition mainly rested upon two presumptions: First, with a two-round system of election, competition would be centripetal. Thus, in order to win in the second ballot a candidate

${ }^{21}$ Mahler, Forming of the Netanyahu Government, pp. 4-5, and U. Lynn, "Labour Supporters Turned Saboteurs", Jerusalem Post, 24 June 1994.

${ }^{22}$ Susser, Direct Election of the Prime Minister, p. 240.

${ }^{23}$ A. Scheman, Electoral Reform in Israel, An Abstract, Tel Aviv, 1990, p. 20.

${ }^{24}$ Ibid., p. 21; and R. Y. Hazan, "Presidential Parliamentarism: Direct Popular Election of the Prime Minister, Israel's New Electoral and Political System", Electoral Studies, Vol. 15, No. 1, 1996, p. 19. 
would have to appeal to the floating vote in the centre; therefore, a successful candidate would probably come from the moderate rather than extreme right or left. ${ }^{25}$ Secondly, many electorates would inherently incline to support the same party (explicitly, Labour or Likud) with that of the candidate for prime minister whom they would vote, since "splintering of the vote would no longer be rational in terms of electoral success" 26 . Therefore, by fortifying the two major parties and weakening the position of the small ones, the changing electoral bchaviour would decrease the number of parties within the Knesset.

After heated debates and endless political manoeuvring a circumscribed form of the reform bill was finally adopted by the parliament on its last day before disbanding. On 18 March 1992, the Knesset enacted the new Basic Law: The Government (beginning with the elections scheduled for May 1996). ${ }^{27}$ As put forward above, the primary aim of the reform was to strengthen the prime minister vis- $d$-vis the Knesset and extortionist small factions in particular. However, the March 1992 amendment to the Basic Law: The Government did not go far enough in fortifying the independence of the prime minister. The Knesset diluted the powers of the prime minister that were proposed by the early drafts of the reform bill, by passing two amendments which stipulated that the parliament would approve the appointment of ministers and allow an absolute majority (61 MKs) instead of the more weighted majority of 70 to force the premier's resignation. ${ }^{28}$ The adoption of this emasculated reform led many outspoken opponents of the law to raise their complaints about the new system. For instance, Diskin of the Hebrew University of Jerusalem called the law "constitutional disaster". ${ }^{29}$ To those who raised their voice against the direct election speculated that the direct election of the premier would greatly increase the leverage of small especially ultra-orthodox parties. Since once voters would have

${ }^{25}$ V. Bogdanor, "The Electoral System, Government, and Democracy", in E. Sprinzak and L. Diamond (eds.), Israeli Democracy Under Stress, London, 1993, p. 98.

${ }^{26}$ Arian, The Second Republic, p. 193.

${ }^{27}$ Hazan, Presidential Parliamentarism, p. 27.

${ }^{28}$ Editorial "Emasculated Reform", Jerusalem Post, 10 January 1992.

${ }^{29}$ E. Gordon, "Stable Democracies Do Not Elect Prime Minister Directly", Jerusalem Post, 08 June 1995. 
chosen the premier directly, they would feel free to support the smaller parties. ${ }^{30}$ In addition, it was also predicted that the new system would boast the dirty politics and extortion of small parties. The pillar of this supposition was that the prime minister would continue to need small parties, both to ensure his personal election and to form a coalition after the Knesset elections. ${ }^{31}$ Therefore, he would be ready to pay any price and pursue every avenue to get their support. In short, as maintained by many opponents, the new law would not end the existing distasteful activities such as political bribery, corruption and blackmailing but it ensured that there would be two rounds of all these ${ }^{32}$ : while the first would take place before the elections for premier, the second would take place when the prime minister-elect tries to secure the support of 61 Knesset members for his government. ${ }^{33}$

Up to this point I have briefly summarised the situation in which the new reform emerged. In diagnosing the malaise of Israeli political system I have also reported some symptoms which are common to many malfunctioning democracies such as political corruption, bribery, extortion and prolonged coalitional negotiations. However, what makes Israel different from other democracies is that Israel invented its own unprecedented "magic remedy" for curing the ills of nation. Falling in an irresistible tornado, many Israelis could not imagine that a change in the rules would not make politicians honest, officeholders responsible and voters wise. Like other laws, the electoral laws have also their unintended consequences besides their primary aims. The experiences of many developing or immature democracies have so far proved that due to these unexpected results, the prescribed remedy is often to be worse than the illness itself. Thus, in the following, by attempting to discover these side-effects in the case of Israel, having experienced an untested remedy, I will elaborate on the various features of the direct election and its implications on the Israeli political system.

${ }^{30}$ C. Herzog, "Half Baked Reform", Jerusalem Post, 20 January 1995.

${ }^{31}$ I. Galnoor, "Strong, But Wrong, Medicine", Jerusalem Post, 24 November 1991.

${ }^{32}$ S. Avineri, "Pious Fallacy of Electoral Reform", Jerusalem Post, 29 January 1992.

${ }^{33}$ S. H. Rolef, "Direct Elections Won"t End Horse-Trading", Jerusalem Post, 23 February 1996. 


\section{The New System}

Israel has a new electoral system combining the previous system of election to the Knesset (under which the Knesset had selected the prime minister, as customary in parliamentary systems) with the new direct elections for the prime minister. The new Basic Law: The Government, which came into effect with the May 1996 elections, sets out a detailed legal framework for the new system. Under the provisions of new law, the prime minister shall be elected in the same national general election as the Knesset but by a separate, direct ballot. The candidate for prime minister may be nominated by a party or group of parties with at least 10 seats in the outgoing Knesset, or by 50,000 enfranchised persons. The candidate must be a citizen at least 30 years of age, and must head his or her party's list of candidates for the Knesset.

The law indicates that should no candidate receive more than half of the valid votes in the first round, then two weeks later, runoff elections are to be held between the two candidates with the highest votes. In the second ballot the candidate receiving the largest number of valid votes becomes prime minister. Following the elections, the prime minister-elect has 45 days to present his or her cabinet and receive a confidence vote from the Knesset. The number of ministers, including the prime minister, must not exceed 18 or be less than 8 . In addition to the prime minister, at least one half of the ministers must be Knesset members. Should the prime minister-elect not successfully present a government to the Knesset within 45 days, special elections for the prime minister will be held within 60 days. ${ }^{34}$ If the same candidate is once again elected and fails to present a government within a second 45 days, new elections are to be held once more but that candidate may not stand for election in the third round. The new system also provides that the tenure of the prime minister and the Knesset shall be four years long and they shall be elected simultaneously unless Knesset elections must be repeated (i.e. as a result of faulty elections) or the law calls for a special election of the prime minister.

With the inauguration of direct elections for prime minister, procedures for dissolving the Knesset have been amended. New

${ }^{34}$ Mahler, Forming of the Netanyahu Government, pp. 5-6. 
elections for the Knesset and the prime minister are held when the Knesset rejects the list of ministers proposed by the prime minister; when at least $61 \mathrm{MKs}$ support a vote of no-confidence in the prime minister, when the Knesset fails to adopt the Budget Law within the three months after the beginning of the fiscal year; when the Knesset dissolves itself by passing a special law to that effect, or if the prime minister, after notifying the president, resigns and dissolves the Knesset. Special elections for the prime minister are to be held when at least 80 members of the Knesset vote to remove him from office. The Knesset may also remove the prime minister by a regular majority vote due to a conviction on an office involving moral turpitude; if the prime minister is unable to appoint the specified minimum of eight ministers to form his government; or if he is permanently unable to fulfil his functions. ${ }^{35}$

In contrast, Isracl's Knesset is elected by a proportional representation list system. According to Basic Law: The Knesset, these elections are held every four years unless earlier elections are called. All registered parties may run in the election. Registration of parties is regulated by law and is quite easy, providing that the party does not oppose the existence of Israel as a Jewish and democratic state. One hundred citizens may apply to the responsible official to be recognised as a political party. A party not represented in the outgoing Knesset that wishes to run in the next elections must also submit the signatures of 1,500 supporters. The minimum age for a candidate is twenty-one. ${ }^{36}$

Lastly, there are no electoral districts and the whole country serves as a single nation-wide constituency. There is only one list of candidates representing each of the political parties. ${ }^{37}$ Thus, every Israeli citizen eighteen years of age or older chooses the entire list as submitted and cannot indicate any preference concerning individual candidates on that list. ${ }^{38}$ If the list submitted

${ }^{35}$ H. Stellman, "Electing A Prime Minister and A Parliament: The Israeli Election 1996", Parliamentary Affairs, Vol. 49, No. 4, 1996, p. 651.

${ }^{36}$ A. Arian, Politics in Israel, New Jersey, 1989, pp. 133-142.

${ }^{37}$ A. Brichta, "Forty Years of Struggle for Electoral Reform in Israel, 194888", Middle East Review, Vol. 21, No. 1, 1988, pp. 18-19.

${ }^{38}$ D. Peretz and G. Doron, The Government and Politics of Israel, Oxford, 1997, pp. 118-119. 
by the party (or a group of parties) receives 1.5 per cent or more of the vote, it wins representation in the 120 -seat Knesset. Votes are counted on a nation-wide basis, and Knesset seats are allocated in direct proportion to the strength of the list at the polls. For instance, if a party wins a third of the vote, roughly entitling it to forty seats, the first forty names on the list becomes members of Knesset.

Up to this point, I have outlined the new electoral system. Under the provisions of this system the 1996 and 1999 elections were held. In the rest of the paper, I will strive to scrutinise the implications of these recent elections upon the Israeli political structure and the party system in particular.

\section{The Implications of Direct Elections}

When analysing the consequences of the new system, one has to find relevant answers to these following questions: First, what were the objectives of the law as formulated by its authors, and were they actually achieved? Second, what did the critics claim would occur when the prime minister was elected directly? And, were these predictions borne out by the facts on the ground? ${ }^{39}$

In striving to answer these queries, it might be claimed that initially, the formulators of the new system wished for it to be clear, as soon as the elections results were tabulated, who would be prime minister and who would form the government. As far as this limited objective is concerned, there can be little doubt that direct elections system has accomplished its purpose fully. The other expectations of the proponents of the new system were that it would invigorate the prime minister; ameliorate the problem of undue small parties; promote the bipolarity and increase the centripetal tendencies in the party system..$^{40}$ On the contrary, what the last two elections bore out is that none of these aims have been achieved so far. However, many supporters still continue to advocate the correctness of the new system by putting forward counter arguments and attributing to all negative consequences to other reasons. For example, while Uriel Lynn, the former chairman

${ }^{39}$ Susser, Direct Election of the Prime Minister, p. 238.

${ }^{40}$ Brichta, The New Premier, pp. 189-192. 
of the Knesset Law Committee and one of the initiators of the reform bill, was elucidating the shrinking of the two large parties by their incapacity and past failure to meet the voters' expectations and needs rather than reckoning it as a result of the new system, ${ }^{41}$ another proponent argued that the Hebron deal and perpetuation of the implementation of the Oslo Accords thanked to direct elections; otherwise, it would have been impossible under the old system. 42

At this point, dealing with the second question, it might be quite useful to recall the omens revealed by many "doomsayers" concerning the potential consequences of the new system just before the elections in 1996 and 1999. They claimed that negotiations between the coalition-maker and its potential electc-? partners would be even more intense and unprincipled than before. This would increase rather than diminish the bargaining power of small parties. ${ }^{43}$ Furthermore, it was also asserted that direct election would lead to political fragmentation by fortifying the smaller parties at the expense of larger ones. ${ }^{44}$ On ground of evidences handed out by the recent elections in 1996 and 1999, it should be noted here that whereas the critics on extreme fractionalisation due to split-voting were totally right, with regard to the opponents' first claim, it is more difficult to reach a final judgement because of the contrasting results posed by those two consecutive elections. While many commentators were attributing Netanyahu's quick coalition formation process (almost two weeks) to the new system and its efficiency, these arguments ceased to be convincing after Barak's seven weeks long coalition bargaining following the May 1999 elections. ${ }^{45}$ Lastly, it should be also recorded here that some critics mentioned the possibility of facing a hostile Knesset for the directly elected prime minister. However, it has been so far proved

${ }^{41}$ U. Lynn, "The Root of All Evil?", Jerusalem Post, 12 December 1997; and "Direct Election Revisited", Jerusalem Post, 13 November 1998.

${ }^{42}$ A. E. Shapiro, "Fixers and Wreckers", Jerusalem Post, 14 March 1997.

${ }^{43}$ Susser, Direct Election of the Prime Minister, p. 242.

${ }^{44}$ U. Benziman, "Thirty-Three Parties Looking For An Edge", Ha'aretz, 06 April 1999.

${ }^{45}$ D. Sharrock and D. Hudson, "Peace First, Barak Tells MPs As He Unveils Dovish Cabinet", The Guardian, 07 July 1999. 
that the prospect of an oppositional Knesset, although surely not impossible, is quite remote. ${ }^{46}$

Finally, after a refinement, the consequences and implications of the new system might be summarised as follows: changing electoral behaviour-split voting, extreme fractionalisation, ascendancy of small parties, emasculation of Labour and Likud, centralisation of power at the hands of prime minister, emerging of the majoritarian trends, personalisation of power, lack of accountability, and aggravation of relations between the executive branch and legislature. Naomi Chazan, a Meretz ${ }^{47}$ MK and the former Deputy Speaker of the Knesset, argues that the combination of all these create a chaotic situation in which autocracy and anarchy coexist. According to her, therefore, this new system makes impossible to rule the country. ${ }^{48}$ With this assertion in mind, in the rest of this paper, we will endeavour to elaborate on these implications in details.

\section{Extreme Fragmentation}

One of the assertions is that direct elections have fostered the already existing fractionalisation in the Israeli party system. However, merely reckoning the numbers of parties and factions within the current Knesset and then comparing this with those numbers of previous Knessets might not help us to confirm this assertion or hypothesis. Since numerical superiority might be misleading. For instance, a fifteen-party Knesset may give us a false impression that it is more fragmented than a thirteen-party Knesset (as Table 1 denotes, the $11^{\text {th }}$ Knesset with 15 parties was less fragmented than the $9^{\text {th }}$ Knesset with 13 parties). Therefore, we need a reliable formula to measure the "effective numbers of parties" and the degree of "fragmentation". In this study, I will mainly use three indices: the Laakso/Taagepera Index of effective

${ }^{46}$ Susser, Direct Election of the Prime Minister, p. 244.

${ }^{47}$ Left wing party. It was formed by Mapam, Citizens Rights Movements (RATZ), and Shinui in 1992.

${ }^{48}$ Interview with Prof. Naomi Chazan at the Knesset, Jerusalem, 29 June 1999. 
number of parties (Nv), ${ }^{49}$ the Molinar Index of number of parties (Np), 50 and the Rae Index of party system fragmentation (F). ${ }^{51}$ The Laakso/Taagepera Index (Nv) quantifies how many parties are in the party system by weighting according to size. However, Molinar argues that "Nv" yields higher values by overcounting the largest party. Thus, he proposes an alternative index (Np) which counts the winning party differently from the rest. In the light of this remark, the scientific scepticism compels me to look at the case of Israel, by using these both indices at the same time. On the other hand, the Rae Index of fractionalisation (F) measures the probability that two randomly selected legislators belong to different parties. It varies from zero (all legislators are members of the same party-zero fractionalisation) to one (each legislator is the only representative of her or his party-extreme fractionalisation). 52

Table 1 shows the effective number of parties and fractionalisation in the Israeli party system. As it may be revealed through the table, Israeli parliament has been always constituted by no less than 10 parties. Comparatively speaking, this number is higher than those of many western democracies. Analysing this

${ }^{49}$ R. Taagepera and M. S. Shugart, Seats \& Votes, New Haven, 1989, pp. 77-91.

50J. Molinar, "Counting The Number of Parties: An Alternative Index", American Political Science Review, Vol. 85, No. 4, 1991, pp. 13831391.

${ }^{51} \mathrm{R}$. Taagepera, "Effective Number of Parties for Incomplete Data", Electoral Studies, Vol. 16, No. 2, 1997, pp. 145-149.

${ }^{52}$ The Laakso/Taagepera Index (Nv) is derived by squaring each party's share of votes, adding all of these squares, and dividing 1.00 by this number.

$$
\mathrm{Nv}=1 / \sum \mathrm{p}_{i}{ }^{2}
$$

Where "Nv" is the number of effective parties expressed in votes and " $\mathrm{p}_{\mathrm{i}}$ " is the fractional share of votes of the ${ }_{i}$ th party. If every party has an equal share of votes, the number of effective parties is equal to the actual number of parties. For unequal party sizes, we usually obtain a fractional value of "Nv". Also, the Rae index (F) can be derived from the effective number of parties through a simple algebraic transformation:

$$
\mathbf{F}=1-\sum \mathbf{p}_{i}^{2}
$$

On the other hand, the Molinar index can be acquired through following formula:

$$
N p=1+N v\left[\left(\sum p_{i}{ }^{2}-p_{i}{ }^{2}\right) / \sum p_{i}{ }^{2}\right]
$$


peculiarity of the Israeli democracy, one may say that the extremely low qualifying threshold has brought about the direct reflection of social cleavages on to parliamentary politics. Whereas there were 11 parties in the outgoing parliament, currently 15 parties are entitled to Knesset seats. However, it is apparent that in the $14^{\text {th }}$ and $15^{\text {th }}$ Knessets, there has been no unprecedented change in terms of number of parties. Since before the change in electoral system, there were Knessets with the same number of parties, such as the $5^{\text {th }}$ Knesset with 11 parties and, the $2^{\text {nd }}$, $11^{\text {th }}$ and $12^{\text {th }}$ Knessets with 15 parties. However, on this ground, it cannot be claimed that nothing has changed with regard to effective number of parties and the degree of fragmentation. Should we read the column indicating the Laakso/Taagepera Index of the effective number of parties (Nv), we notice that while in 1996 it was indicating its third highest rate ever with a six-party system, it reached its zenith with a ten-party system following the 1999 elections. On the other hand, the Molinar Index (Np) yields more striking results. Since it reads that the highest rates are obtained with 4.26 and 6.96 in 1996 and 1999 elections respectively. In discussion of fractionalisation, the Rae Index (F) which inherently releases similar results with the Laakso/Taagepera Index, marks drastic changes in the recent years. Particularly, it is virtually marking an extreme fractionalisation rate with 0.91 in 1999. Therefore, it might be concluded that the quantitative data confirms the oft-repeated cliche that the new electoral system has contributed to further fragmentation of Israeli politics. Hereafter, tackling more practical features of the issue, I shall focus on the causes that have opened the way to this unintended result.

\section{The Changing Electoral Behaviour: Split-Ticket Voting}

There are few Western democracies that face the difficult task of effectively governing a society that possesses as many as social, political and ideological cleavages as is the state of Israel. ${ }^{53}$ The population of Israel is divided along various cleavages such as the Jews and Arabs; Ashkenazim and Scphardim; secular and religious;

${ }^{53}$ A. Diskin, Elections and Voters in Israel, New York, Praeger, 1991, p. 13. 
hawks and doves; "Russians" and differing social classes. 54 Moreover, these cleavages often occur as overlapping divisions posing a possible danger to Israeli democracy. In terms of reported voting behaviours, while many religious, Sephardim, less educated and lower-status workers tend to vote for the Likud and religious parties, the other group having a disproportionate share of secular, upper-class Ashkenazim mostly vote for Labour and Meretz. ${ }^{55}$ Having ideologised the existing divisions, this correlation between the voting behaviour and social, ethnic, and religious identity has polarised the society around the two major parties and their components. According to Asher Arian, this reported importance of identification with the party peaked in the 1980s prior to introduction of direct elections. It is also argued that Israeli voters were loyal to their parties and tended to support them regardless of the issues presented and the personalities heading the lists, ${ }^{56}$ since under the old system, the only way to influence the election of the prime minister was to vote for the larger parties. However, voters who in the past oscillated between a major party and one of its potential coalition partners, but cast their single ballot for the major party not to waste their vote no longer have to decide. ${ }^{57}$ With regard to recent elections, what appears to be the case is that the split-ballot system was in a sense "liberating" for Israeli voters. ${ }^{58}$ Apparently, with the direct election of the prime minister most voters, after having cast their votes for the prime minister, inclined to vote for one of the small parties close to their hearts. ${ }^{59}$ The logic of this new electoral behaviour was pronounced by the brilliant electoral slogan of the Third Way that compared voting for the same party in both prime ministerial and party vote to "putting bread in pita". 60

Table 2 shows that in practice this happened often in 1996 and 1999 elections. While in May 1996, 50.5 per cent of the valid

\footnotetext{
${ }^{54} \mathrm{~S}$. Smooha, "Class, Ethnic, and National Cleavages and Democracy in Israel", in E. Sprinzak and L. Diamond (eds.), Israeli Democracy Under Stress, London, 1993, p. 309.

55 Arian, The Second Republic, pp. 210-214.

56D. Peretz and G. Doron, The Government and Politics, p. 143.

${ }^{57}$ Hazan, Executive-Legislative Relations, p. 343.

${ }^{58}$ Mahler, Forming of the Netanyahu Government, pp. 13-14.

${ }^{59}$ M. Arens, "Beware False Remedies", Jerusalem Post, 31 January 1996.

${ }^{60}$ Susser, Direct Election of the Prime Minister, p. 247.
} 
votes were cast for Netanyahu for prime minister, only 25.8 per cent of the valid votes were cast for the Likud list of candidates for the Knesset. Similarly, while 49.5 per cent of the valid votes were cast for Peres, only 27.5 per cent of the valid votes were cast for the Labour list of Knesset candidates. The situation became worse in May 1999. This time, while the incumbent prime minister received 43.9 per cent, his party was entitled to only 14.1 per cent of the valid votes. The picture for Labour was even worse. While 56.1 per cent of the valid votes were counted for Barak, Labour received only 20.3 per cent. This means that nearly 52 per cent of Israeli voters chose a prime minister of one party and Knesset candidates from another party in 1996 . This vote-splitting rate reached almost 65 per cent in 1999.

It has been argued that this changing electoral behaviour or split-ticket voting has aggravated political fragmentation by empowering the "smaller" partics at the expense of the larger and ideological ones. However, the results of the last two elections indicated that this assertion is not true, but not wrong at all. Therefore, it needs to be modified. In analysing the impact of the new system, it should be noted that it did not increase the electoral power of all small parties. As Table 3 denotes that while Meretz lost 3 seats, United Torah Judaism (UTJ) only retained its parliamentary share in 1996. Moreover, the results of the 1999 elections represent a more confusing picture. Since, Table 3 reads that while Y'Israel Be'aliyah has declined from 7 seats in 1996 to 6 seats in 1999, the Third Way lost its all 4 seats and Hadash lost 2 of its 5 seats in the 15th Knesset. However, an analysis based on blocks rather than individual parties might be more helpful. Hence, referring to Table 3, it may be underlined that Arab parties, religious parties and Russian parties have increased their representation in the current Knesset. On the contrary, the results concerning the two large partics indicate a drastic decline from 1992 to 1999 . While the Likud fell down from 32 seats in 1992 to 22 seats in 1996 and to 19 in 1999; Labour faced a more dramatic panorama which is an extreme fall from 44 seats in 1992 to 34 seats in 1996 and to 26 seats in 1999. Therefore, in the light of given data, it should be concluded that the new system has favoured the ethnic, sectarian and religious partiesbut not all small parties at the expense of ideological and major parties. 
Hereafter, I will elaborate on the reported implications of the split-ticket voting on the individual parties and blocks. Initially, I will commence my analysis with religious or ethno-sectarian parties.

\section{- Proliferation of Ethno-Sectarian Parties}

Split-ticket voting was the dominant feature of the 1996 and 1999 elections. In this respect, Table 2 reveals that communities with strong concentrations of observant Jews, nominally Bnei Brak (largely haredi, ultra-orthodox non-Zionist) and Jerusalem (both haredi and orthodox-Zionist) have the highest vote-splitting rates with the "non-Jewish settlements" (mainly Israeli Arabs) and Nazareth (largest Arab city in the country). It implies that these communities are those who gained the most from the new electoral system although the change in electoral laws was motivated by the desire to reduce the power of small parties and religious parties in particular. Put in other way, benefiting from the dual-ballot system, orthodox religious voters gave a rise to their sectarian parties by means of the second ballot. ${ }^{61}$

The religious parties generally have received about 15 percent of the vote, although in 1996 and 1999 this shot up to 20 per cent (meaning 23 seats in 1996 and 27 seats in 1999) and they were regular coalition partners in the majority of governments, whether headed by Labour or Likud. The surge of the religious parties in the last two elections was based on broad ethnic support, with different ethnic groups supporting the three religious parties. United Torah Judaism (UTJ) was largely Ashkenazi, Shas mostly Sephardi, and the National Religious Party (NRP), drawing its support from both ethnic groups. ${ }^{62}$ With regard to electoral performance of each party, it should be recorded that Shas has indicated the most stable progress since 1984 by increasing its share of votes. Since then, it has permanently multiplied its support among the traditional Scphardim. It also seems to have attracted many voters who were not necessarily religious but had benefited in some way from its extensive network of social services and free

${ }^{61}$ M. Arens, "First Things First", Ha'aretz, 20 August 1998.

${ }^{62}$ Arian, The Second Republic, pp. 213-221. 
education opportunities. ${ }^{63}$ Parallel to its increasing power, Shas replaced the NRP as pivotal party and became the only religious party in Rabin's coalition government in 1992. Shas maintained its position in Netanyahu and Barak governments following the 1996 and 1999 elections.

\section{- Ascendancy of Arab Sector}

Adoption of direct elections was welcomed in the Arab sector whose majority has traditionally voted for Labour or parties that support Labour coalition. It was expected that new system would empower the Arab parties' bargaining power. Since Labour's candidate needed full backing of Isracli Arabs to become prime minister, Arab parties would presumably find themselves in a stronger position to exact concession from Labour. A second assumption was that Arab electorate would finally manage to convert its numerical strength into political influence. ${ }^{64}$ In fact, Arab parties managed to increase their representation from 5 seats in 1992 to 9 seats in 1996 and to 10 seats in 1999. However, it is still far from reflecting their real potential. Israeli Arabs currently number about one million people (around the 18 per cent of Israel's population). Approximatcly, 480,000 of them (12 per cent of the entire Israeli electorate) are of voting age. Therefore, if voting as a monolith, Isracli Arabs could elect 14 members to the Knesset. However, ideological and personal rivalries among Arab politicians have always prevented them from forming a common list. It was also true that mainly Labour, Meretz and Likud have attracted nearly 30 per cent of the valid Arab votes in 1996 and 1999.

With regard to first supposition, initially it should be stated that it was an inflated expectation. The majoritarian winner-take-all system turned the electoral process into a zero-sum game. In contrast to Knesset elections, the race for prime minister did not offer much of a choice: there were only two candidates both in 1996 and 1999. In this sense, all voters had three options: the

${ }^{63}$ D. Peretz and G. Doron, "Israel"s 1996 Elections: A Second Political Earthquake", Middle East Journal, Vol. 50, No. 4, 1996, pp. 537-538.

${ }^{64} \mathrm{G}$. Denoeux and J. Fox, "Electoral Upset in Israel", Middle East Policy, Vol. 4, No. 4, 1996, pp. 26-28. 
candidate of Likud, Labour candidate or not voting. In theory, Arab voters had the same three options as the rest of the electorate; in reality voting for Netanyahu was not considered a pragmatic option because of the right's position on domestic and foreign policy issues important to the Arabs. There were only two choices: Labour candidate or abstention. For instance, the massive preference for Peres (94.8 per cent of the valid Arab votes) despite the Operation Grapes of Wrath, the closure of the occupied territories is in fact the tangible manifestation of the political dilemma of the Arabs in Israel. During the 1996 and 1999 electoral campaigns it was quite obvious that the Arabs had no serious alternative to voting for the candidate of the Labour Party. This left them no room to manocuvre or hold out for rewards for their support unlike the small religious parties or immigrant lists. ${ }^{65}$

\section{- Rise of Single-Issue Parties}

The other ethnic group running for the Knesset was the Russian immigrants. Following the demise of the Cold War, nearly 700,000 Soviet Jews made Aliyah. ${ }^{66}$ Highly secular, educated and qualified Russian immigrants have had difficulties in integrating with Israeli society. ${ }^{67}$ Having failed to find solutions to their problems, both Likud and Labour governments disappointed the Russian community. In this environment, Y'Israel Be'aliyah was formed by Natan Sharansky to articulate these dissatisfactions in March 1995. As a single-issue or special-interest party, ${ }^{68}$ this new comer to Israeli politics declared that its major long-term objective was to bring another one million Jews to Israel. In addition to its leader's enormous popularity and the disenchantment of its supporters with the two major parties, the new electoral law also gave extra support to this new list. As a result, Y'Israel Be'aliyah secured 7 seats in the $14^{\text {th }}$ Knesset. Prior to the elections to the

${ }^{65}$ A. Ghanem, "The Limits of Parliamentary Politics: The Arab Minority in Israel and the 1992 and 1996 Elections", Israel Affairs, Vol. 4, No.2, 1997, pp. 72-93.

${ }^{66}$ Waves of mass immigration to Israel. Literally, going up or rise in Hebrew.

${ }^{67}$ Y. Sezgin, "Sovyet Yahudilerinin Siyasal ve Toplumsal Yaşama Etkileri", Şalom Gazetesi, 18 June 1997.

${ }^{68}$ M. Arens, "Anarchy At the Gate", Jerusalem Post, 25 September 1998. 
$15^{\text {th }}$ Knesset, another Russian list, Y'Israel Beiteinu, was formed by the former director-general of the Prime Minister's Office, Avigdor Lieberman. In May 1999, these two Russian lists gained 10 seats in the Knesset (Y'Israel Be'aliyah 6 seats, Y'Israel Beiteinu 4 seats). Ethnically speaking, this meant a 42 per cent increase in the Russian sector's representation in parliament.

In the 1996 elections, the other emerging single-issue party scoring impressive results was the Third Way. In an environment escalated by growing anger to Labour's "territorial compromises", it was formed by an interest group within the Labour party and was led by a Jewish settlement leader from the Golan Heights, Avigdor Kahalani. Since its primary objective was to keep the Golan Heights under Israeli rule, it opposed the peace talks with Syria. The Third Way declined to support either Peres or Netanyahu for prime minister, although many of its former members voted for Peres. Indeed, the party portraying itself as an agent of national consensus capable of bridging the gap between the moderate segments of the right and the left, positioned itself somewhere in the centre between Labour and Likud. While it managed to seize 4 seats in 1996, in the last elections it could not pass the one-and-half per cent qualifying threshold as it won only 0.7 per cent . This dramatic decline has been explained by the emergence of The Centre Party and Shinui in the centre of the political spectrum, and the fading of the Golan Heights issue in the last elections.

\section{- Decline of Major Parties}

Figure 1 denotes the electoral performance of the two major parties and middle-sized parties receiving more than 5 per cent of the valid votes in the last two decades. It appears that after a peak in 1981 (73 per cent) the total share of both Labour and Likud have diminished very consistently since that year. This rate fell to 66 per cent in 1984, to 61 per cent in 1988, to 60 per cent in 1992 and to 53 and 34 per cents in 1996 and 1999 respectively. In this respect, the criticism that the new electoral system has brought about the decline of the major partics is unfounded. ${ }^{69}$ As shown in Figure 1, this decline had started before. However, it should also be noted

${ }^{69} \mathrm{C}$. Klein, "Direct Election of the Prime Minister in Israel: The Basic Law in its First Year", European Public Law, Vol. 3, No. 3, 1997, p. 310. 
that according to Figure 1, in 1996 and 1999 a more dramatic decline occurred while the numbers of middle-sized parties increased. In terms of scores recorded by both major parties, it might be noted that while Likud saved itself from a sharp upset because of its last minute coalition with Tsomet and Gesher, Labour faced a serious decay from 34.7 per cent to 27.5 per cent in $1996 .{ }^{70}$ In 1999, although, this time, Labour endeavoured to protect itself against further ebb and engaged with Gesher and Meimad, it could not reverse the trend and received 20.3 per cent. Furthermore, Likud had performed no better than Labour by falling down to 14.1 per cent. The more derogatory point was that Likud was almost being replaced by Shas as the second main party. Therefore, it might be argued that the fall of major parties has been accelerated by the two-ballot system. In other words, it was only a catalyst rather than a "scapegoat" for which supporters of both parties were looking.

At this point, endeavouring to analyse the causes of this decline, I should briefly touch upon the tactical mistakes made by both parties in the electoral campaigns rather than merely reporting what happened in the 1996 and 1999 elections. According to Susser, although both parties understood early the unprecedented logic of direct electionvictory in the prime ministerial vote is considerably more important than the results of the party vote they seem to have exaggerated this priority into a thoroughly lopsided division of energies. All the party's resources were focused on victory in the prime ministerial contest, while virtually nothing was invested in convincing voters that a good party showing was an integral part of electoral success. They did not even bother to distinguish themselves from their potential coalition partners, to say nothing about directly attacking them as was the common practice in previous elections. ${ }^{71}$ Among the other causes I can mention the recent Peace Process that has changed the electoral attitudes of both the electorate and parties, worsening economic situation, proliferation of religion within society and politics, secular versus orthodox polarisation, rising dissatisfaction of 700,000 new olim (Jewish immigrants), emergence of new central parties, and incapability of both parties to adapt themselves

\footnotetext{
${ }^{70}$ N. Lochery, The Israeli Labour Party, Berkshire, 1997, pp. 259-263.

${ }^{71}$ Susser, Direct Election of the Prime Minister, pp. 247-250.
} 
to changing conditions. ${ }^{72}$ In addition, many discontented voters have chosen to punish Labour and Likud for their corruption and maladministration in bureaucracy and politics. ${ }^{73}$

I have so far presented a brief framework in discussion of split-ticket voting and its consequences. It has been proved that this changing electoral behaviour caused further atomisation of the Israeli party system by catalysing the decline of major parties and encouraging sectarian, ethnic and single-issue parties. This unintended result was welcomed by many proponents of the new law since they have argued that the new system provides an equitable and democratic framework within which the voters can satisfactorily signify their choice. ${ }^{74}$ As a result, however, one cannot say that Israeli society has become more democratic than before 1996. Conversely, in a highly fragmented society, such as Israel, emergence of a few mass centre parties undifferentiating social, ethnic, and sectarian cleavages with some other middle-sized or peripheral parties might provide a more stable and favourable democratic environment.

\section{The New Coalition Politics}

In no election has a single list of candidates ever won an absolute majority of votes or an absolute majority of Knesset seats. Yet no government has ever been established in Israel that did not have, at least at the time it was formed, the support of the majority of Knesset members. ${ }^{75}$ Thus, every Isracli government has been based on a coalition which was comprised of an absolute majority of Knesset members from various factions. ${ }^{76}$ However, this is not to say that Israel has enjoyed stable and nourishing coalitions

${ }^{72} \mathrm{G}$. Goldberg, "The Electoral Fall of the Israeli Left", Israel Affairs, Vol. 4, No. 1, 1997, pp. 53-71.

${ }^{73}$ Y. Goell, "Whose Fault", Jerusalem Post, 05 July 1999.

${ }^{74}$ O. Shohat, "The Dilemma of Direct Elections", Ha'aretz, 27 November 1998.

${ }^{75}$ The $26^{\text {th }}$ government formed by Peres began with the formal support of only fifty-six MKs. However, the special conditions that existed after the assassination of Rabin allowed the government to continue through elections a half-year later.

${ }^{76}$ A. Diskin, Elections and Voters, p. 177. 
throughout its history. As it was elucidated earlier, coalition governments have been extremely vulnerable to extortion by their small partners. The architects of the new system were seeking to insulate the prime minister from this kind of pressure, and felt that direct election of prime minister was an effective way to do this.

Below, I will look at the implications of the new system on coalition formation process and attitudes. In the light of the last two elections, initially it should be said the extent of bargaining with small and middle-sized sectarian parties to form the coalition was as great as in the past. ${ }^{77}$ The examples of Netanyahu and Barak governments illustrated that prime ministers were still as dependent as their predecessors on their coalition partners. After merely two years in the office, it became quite obvious that both prime ministers were incapable of governing the country because of endless cabinet crises. Consequently, having lost their majority in the Knesset they both called for early elections.

Direct election of the prime minister has altered the classical coalition-building process. Both Netanyahu and Barak negotiated with their potential coalitional partners from a position of strength and exclusivity because there were no other alternatives open to the small parties (yet under the old system small parties were in a position to decide who would be prime minister). Especially, in the case of power-addict sectarian parties such as NRP and Shas, joining the coalition, which meant influence, budgets, patronage, and ministries, became a vital issue regardless of its cost. For instance, needing the government allocations to nurture its impressive network of schools, educational programmes, day-care centres and charities, ${ }^{78}$ Shas did not hesitate to dismiss its leader Aryeh Deri to launch coalition negotiations with Barak following the elections in $1999 .{ }^{79}$

${ }^{77}$ A. Arian, "The Israeli Election for Prime Minister and the Knesset, 1996", Electoral Studies, Vol. 15, No. 4, 1996, p. 574.

${ }^{78}$ Denoeux Fox, Electoral Upset in Israel, p. 126.

${ }^{79}$ Meretz declared that it would not take a place in the same government with Shas as long as it was headed by Deri who was free pending an appeal against a four-year prison sentence for bribery and corruption. P. Kidron, "Barak Courts the Right", Middle East International, No. 601, 4 June 1999 , pp. 4-6. 
Under the previous single-ballot system, the heading party in the government usually controlled 40 or more Knesset seats, and needed to win over no more than two or three lesser factions to boost its numbers to the required 61 majority. ${ }^{80}$ However, under the new system, because of the fact that two major parties drastically lost their power, both Netanyahu and Barak had to negotiate with almost every small party or faction to reach the required absolute majority. Parallel to their increasing vigour, small parties came to ask for higher demands in these coalitional negotiations. As a result, while the number of ministries held by small parties multiplied, both Likud and Labour faced the bitter reality of controlling less than a majority within their own governments.

Lastly, another problem confronting the directly elected premiers was the allocation of the limited number of cabinet seats. The new law restricted the maximum size of the cabinet to 18 members. Given that ceiling, Netanyahu and Barak faced the problem of making sure that they had enough Likud and Labour members in their cabinets while at the same time giving their coalition partners an acceptable level of cabinet positions. While Netanyahu created a new super ministry for Ariel Sharon to satisfy the various factions within Likud, Barak expanded his government from 18 to 24 to ensure "the proper representation for each of the seven coalition parties by amending Basic Law: The Government". ${ }^{81}$ Opposing this expansion, Chazan a prominent member of Meretz which was Barak's coalition partner, said that financially this would raise the cost of the executive branch by hundreds of millions of shekels every year. ${ }^{82}$

\section{The Absence of Checks And Balances}

Many critics argue that the new law has failed to provide any checks and balances normally considered necessary where central authority is vested in the chief of executive, such as those provided

${ }^{80}$ P. Kidron, "Coalition Dilemmas", Middle East International, No. 602, 18 June 1999, pp. 6-8.

${ }^{81}$ P. Kidron, "Barak Charts His Course", Middle East International, No. 604, 16 July 1999 , pp. 4-6.

${ }^{82}$ N. Chazan, "Compact and Accountable", Jerusalem Post, 09 July 1999. 
by the United States constitution. ${ }^{83}$ In the new system, partly by design, partly by accident the directly elected prime minister has become much more uncontrolled and autonomous vis-d-vis the legislature. However, according to Arian, the executive branch in Israel always had disproportionate importance compared to the legislative branch. In this sense, the new system has only contributed to further exacerbation of the situation. ${ }^{84}$

The critics are mainly targeting their arrows at three points that are the increasing uncontrolled power of the prime minister, emasculation of the Knesset and the changing feature of the relations between the executive and legislative branches. Hereafter, in discussion of checks and balances in the Israeli system, I will attempt to provide a general framework by assessing these arguments.

Initially, it should be noted that many social scientists and analysts have criticised the introduction of a majoritarian system into a heterogeneous society that requires consensus structures such as Israel. ${ }^{85}$ Since, decisions about going to war, signing a peace and fixing permanent borders are matters which require a broad-based consensus, one that can hardly be commanded by a prime minister elected by a razor-thin majority of the eligible voters (for instance, by relying on his bare plebiscitarian majority 50.4 per cent Netanyahu had profoundly divided Israeli society in pursuing his highly personal policy towards the Peace Process and implementation of the Oslo and Wye Plantation accords in particular). It is also claimed that adoption of direct election has to be balanced by codification of a constitution with formal guarantees of fundamental rights. ${ }^{86}$ This is because the existing Basic Laws ${ }^{87}$ are inadequate to provide the citizens and the Knesset

${ }^{83}$ D. Capitanchik, "The Israeli Gencral Election of 1996-Another Upheaval", Government and Opposition, Vol. 31, No. 4, 1996, p. 452.

${ }^{84}$ Arian, The Second Republic, pp. 238-239.

${ }^{85} \mathrm{~L}$. Diamond and E. Sprinzak, "Directions for Reform", in Sprinzak/Diamond, Israeli Democracy Under Stress, pp. 365-366.

${ }^{86}$ Scheman, Electoral Reform in Israel, p. 22.

${ }^{87}$ In March 1992, Israel also enacted two new Basic Laws on freedom of occupation and human dignity. 
with a shelter against the emergence of a premier with dictatorial powers. $^{88}$

The dual-ballot system puts enormous power in the hands of the prime minister. It is true that the individual elected was chosen to have that power, but power unchecked is a dangerous commodity in a democracy. The troubling dilemma for Israel's democracy is the emergence of a leader popularly elected but unaccountable to his party and cabinet. ${ }^{89}$ The premier takes on the role of producer and director of the entire show. As the secretarygeneral of the Labour Party asserts "[the prime minister] does not allow ministers to participate in decision-making; he comes to meetings with his mind made up; and receives information from out side sources, which he trusts" and he continues "after all, we have a very dominating prime minister, who casts a shadow over the entire government". 90

The new system underscores the strength of the prime minister and the weakness of the Knesset even more forcefully. The prime minister and the ministers who are the leaders of the ruling coalition partners in effect totally control the legislature by imposing the whip of party discipline over their respective party backbenchers. ${ }^{91}$ Furthermore, by taking away the weapon of the no-confidence motion, the new law has left the Knesset totally powerless. While in the past losing a vote of confidence by any majority was sufficient to replace the government within the parliament, now it requires at least a majority of 61 Knesset members to pass a no-confidence motion in the prime minister which means early elections for both premier and the Knesset. However, despite this structural weakening, the $14^{\text {th }}$ Knesset (19961999) has witnessed vastly exaggerated use of the no-confidence mechanism. ${ }^{92}$ In other words, the opposition turned the motion of no confidence into a "weckly ritual". 93 With regard to changing

${ }^{88}$ F. G. Cashman, "Newsline With Prof. Uricl Reichman", Jerusalem Post, 21 July 1997.

${ }^{89}$ Arian, The Second Republic, pp. 197 and 243.

${ }^{90}$ Hazan, Executive-Legislative Relations, p. 340.

${ }^{91}$ Y. Goell, "Premier Not Dictator", Jerusalem Post, 24 June 1996.

92 Y. Gocll, "Alive and Kicking", Jerusalem Post, 24 June1997.

${ }^{93}$ S. H. Roleff, "The Weckly No-Confidence Ritual", Jerusalem Post, 15 June 1998. 
behaviour of the legislative branch, Hazan argues that notwithstanding the fact that the opposition is not able to reach the required 61 votes, it often aims to reduce the popular legitimacy of the prime minister by symbolically defeating the coalition parties by any simple majority since the coalition parties habitually abstain from these confidence votes. ${ }^{94}$ This new attitude continued in the $15^{\text {th }}$ Knesset, while the opposition attempted to bring down the Barak government in its first three weeks by presenting four motions of no-confidence. 95

On the other hand the proponents of the new law argue that the Knesset is not relegated to an inferior status vis-a-vis the popularly elected prime minister. In a speech to the parliament, David Libai, claimed that still the prime minister must formı a coalition since this is not a one-man rulc. Therefore, if he wants to pass laws or his budget he must appeal to majority in the Knesset. ${ }^{96}$ Susser of the Bar-Ilan University notes that the new law has even reinforced the Knesset to counterbalance the enhanced premier. In order to epitomise his argument he points to the following new powers of the Knesset: an increase in the Knesset's role in regard to declaration of "state of emergency", its new competence to summon any minister to appear before a Knesset committee (in the past, the minister had to agree to accept such an invitation), and its newly granted ability to vote no-confidence in a single minister (it needs 70 votes) without bringing down the government.

\section{The New Role of the President}

Under the old system, Israel's president assigned the task of forming a new cabinet to the Knesset member considered to have the best chance of forming a viable government coalition based on election results. ${ }^{97}$ This system had a certain degree of flexibility.

${ }^{94}$ Interview with Dr. Reuven Hazan at the Hebrew University, Jerusalem, 27 June 1999.

95 N. Gilbert, "Barak Faces Threc Motions of No-Confidence Today", Jerusalem Post, 26 July 1999.

96 Jerusalem Centre for Public Affairs, Direct Election of the Prime Minister, p. 44.

97Peretz/Doron, Israel's 1996 Elections, p. 530. 
Despite the fact that usually the head of the party, receiving the most votes was appointed prime minister-designate, this principle had few exceptions in practice. For instance, in 1983, Shamir was asked by the president to form a government after prime minister Begin's resignation, even though the Likud's Knesset delegation was smaller than the Alignment's. ${ }^{98}$ However, the new system eliminated the role of the president in selecting the prime minister since the latter is now automatically elected by popular vote.

While, on the one hand, the new system diminished the role of the president by turning him into an extremely symbolic head of state, on the other hand it added a new function to the presidency. According to Basic Law: The Government, Article 22, the prime minister must obtain approval from the president of the state in order to disperse the Knesset. ${ }^{99}$ According to Hazan, this new role of the president puts him in a position above politics and requires him to act as an objective national figure. ${ }^{100}$ Finally, it should be underlined that Basic Law: The President of State has to be amended in accordance with new Basic Law: The Government, since the former legislation still contains some inconsistent provisions with the new role of the president. 101 Therefore, following these necessary amendments the functions and authority of the head of state must be redefined. ${ }^{102}$

\section{Americanisation of Israeli Politics}

Parallel to rising majoritarian trends, with the adoption of direct election for the prime minister, the country's election campaigns have undergone a process of "Americanisation". According to Wilzig, "Americanisation" need not be a matter of blind transferral of American campaign methods and style, for each country has distinctive social and cultural patterns, and one

${ }^{98}$ Arian, The Second Republic, p. 242.

${ }^{99}$ A. Dodek, and E. Block, "New Times, New Needs", Jerusalem Post, 01 September 1996.

${ }^{100}$ Editorial, "Expert: President Has Lost His Credibility", Jerusalem Post, 31 December 1998.

${ }^{101}$ A. E. Shapiro, "A Wisdom Beyond Politics", Jerusalem Post, 04 December 1992.

102Editorial, "Destroying Presidency", Jerusalem Post, 30 June 1998. 
would expect such "borrowing" to be adapted to the receiving political framework in a fashion fitting to that system. ${ }^{103}$ In this respect, I shall mainly touch upon the so-called "personalisation" and "privacisation" of Israeli politics.

As I elucidated earlier, the new electoral system has drawn public attention to the direct election of the prime minister and aftermath of elections to the personality of popularly elected prime minister by putting the parties and the Knesset elections in a secondary position. Despite the fact that the new legislation did not take effect until 1996, the impact of this 1992 reform was already felt during the 13th Knesset, whose parties and politicians behaved as though reform were already in place. Prime Minister Rabin, prior to his assassination, functioned in a manner which many MKs, even those in his party, branded as presidential. ${ }^{104}$ Labour conducted its 1992 election campaign as if these were direct elections for the prime minister. The symbols of the party were changed: "Nationalist" blue replaced red as the party's colour. The rhetoric was also altered; from the usual collective "we", Rabin turned to the charismatic "I" ("I'll lead, I'll guide, I'll determine", "My government" and so on). The Labour party even changed its name before the 1992 election to "Labour Headed by Rabin". 105 These changing characteristics of the electoral campaigns have forced traditional and unpopular leaders into retirement. For instance, following the 1992 defeat, Likud had to replace its old and lacklustre leader with young Netanyahu who was highly conversant with American-style campaigning. As a result of rising public interests in the candidates, appearances of the leaders in media, and hours-long TV debates between the leading candidates have become very manipulatory in the last minute determination of the floating voters.

Israeli elections have traditionally been circumspect about delving into candidates' private lives. Indeed, before the 1992 reform, most Israelis did not even know what their leaders' respective spouses look like. However, the personalisation of

${ }^{103}$ S. L. Wilzig, "The 1992 Media Campaign: Toward the Americanisation of Israeli Elections", in D. Elazar and S. Sandler (eds.), Israel at the Polls, 1992, Maryland, 1995, p. 251.

${ }^{104}$ Hazan, Executive-Legislative Relations, p. 334.

105Peretz/Doron, The Government and Politics, p. 145. 
politics engendered the privacisation of politics as well. The first directly elected prime minister Netanyahu and his wife Mrs. Sara Netanyahu exemplified the case of privacisation in Israel very well. It was hard to see any tabloid newspaper without covering any "Sara affair" during her husband's tenure. Mrs. Netanyahu's lavish and luxurious expenses and capricious attitudes towards their assistants occupied the headlines. Even the Prime Minister's Office's web site was adorned with the Sara's pictures and biography. In this process of de-ideologisation, personalisation and privacisation, the political discourse downgraded its level. The appearance of Sara Netanyahu's photomontaged nude pictures on the Labour Party's official web site in April 1999 marked the heyday of this ethically corrupt privacisation. ${ }^{106}$

\section{Epilogue}

This study has primarily focused on the direct election of the prime minister and its implications on Israeli politics. The analysis commenced by describing the environment in which the new electoral system emerged and followed by outlining the general features of this system. In discussing of the implications of the new electoral law, it was shown that the new system has brought about the rise of small religious and ethnic lists and accelerated the emasculation of major and ideological parties within the Knesset. As a result of this unintended change in the party system, the coalitional politics and government formation processes have been drastically altered. In addition, the changing role of the head of state and the de-ideologisation, personalisation and privacisation or in other words "Americanisation" of Israeli politics has been discussed.

This research has been constructed on the results of the 1996 and 1999 elections. In this regard, it should be borne in mind that any study resting on the data provided during such a limited period and a small number of experiments might prevent us from reaching a clear-cut result. However, with this remark in mind, it may be concluded that in the light of recent elections, Israeli

${ }^{106}$ H. Danna, "Nude Sara Netanyahu Appears on Labour Web Site", Jerusalem Post, 05 April 1999. 
politics has become less stable than it was before the adoption of Basic Law: The Government in March 1992.

As the last two elections of 1996 and 1999 demonstrated, the situation became worse after each election. The opponents of the system have widely argued that the next elections would perpetuate to destabilize the Israeli politics unless the direct elections law was amended. However, without any change, Israel continued to hold special elections for the prime minister in February 2001. Although the Basic Law: The Government of 1992 provided itself with an "immunity" against future changes that the law could not be changed unless supported by a majority of at least 61 Knesset members, a total amendment was possible only after Ariel Sharon became the prime minister of Israel. As part of a coalition agreement between the Likud and One Israel (Labour block), on March 7, 2001, the Knesset overwhelmingly (in a 72-37 vote with three abstentions) decided to repeal the system of direct elections, and restored the one-vote parliamentary system of government that operated until 1996. The new law, which is to take effect in the elections for the next Knesset scheduled in November 2003, will also make a number of reforms to the old parliamentary system such as constructive no-confidence vote, ${ }^{107}$ and the mechanism enabling the prime minister to dissolve the Knesset. However, in order to overhaul the shortcomings of the existing system, Israel must still take this reform process further and increase the qualifying threshold, divide the country into electoral constituencies, and adopt the so-called "Norwegian Law"108 which would strengthen both government and the Knesset, by restoring the checks and balances. At the end, given the fact that Israel can only start recovering the side-effects of the untested remedy after 2003, until then the country would continue to suffer from the serious anomalies caused by the system of direct elections.

${ }^{107}$ A government cannot be toppled in a no-confidence vote without the support of $61 \mathrm{MKs}$, who must also declare support in writing for an alternative government.

${ }^{108}$ This would have ministers automatically resign from the Knesset on being appointed to the government in order to make room in the Knesset for the next person on the party list. 
Table 1: Effective Number of Parties and

Fractionalisation in Israel (1949-99)

\begin{tabular}{|c|c|c|c|c|c|c|}
\hline $\begin{array}{c}\text { Electoral } \\
\text { System }\end{array}$ & Year & $\mathrm{Nv}$ & $\mathbf{N p}$ & F & $\begin{array}{l}\text { No. of } \\
\text { Parties in } \\
\text { Knesset }\end{array}$ & $\begin{array}{c}\text { Qualifying } \\
\text { Threshold } \\
(\%)\end{array}$ \\
\hline $\mathrm{PR}^{*}$ & 1949 & 5.41 & 2.67 & 0.81 & 12 & 1 \\
\hline PR & 1951 & 5.13 & 2.46 & 0.80 & 15 & 1 \\
\hline PR & 1955 & 6.36 & 3.16 & 0.84 & 12 & 1 \\
\hline PR & 1959 & 5.20 & 2.25 & 0.80 & 12 & 1 \\
\hline $\mathrm{PR}$ & 1961 & 5.50 & 2.85 & 0.81 & 11 & 1 \\
\hline PR & 1965 & 4.93 & 2.65 & 0.79 & 13 & 1 \\
\hline PR & 1969 & 3.63 & 1.81 & 0.72 & 13 & 1 \\
\hline PR & 1973 & 3.85 & 2.52 & 0.74 & 10 & 1 \\
\hline PR & 1977 & 5.02 & 3.20 & 0.81 & 13 & 1 \\
\hline PR & 1981 & 3.59 & 2.81 & 0.72 & 10 & 1 \\
\hline PR & 1984 & 4.31 & 3.04 & 0.76 & 15 & 1 \\
\hline $\mathrm{PR}$ & 1988 & 5.02 & 3.58 & 0.80 & 15 & 1 \\
\hline PR & 1992 & 4.92 & 3.00 & 0.79 & 10 & 1.5 \\
\hline $\mathrm{PR}+\mathrm{DE}^{*}$ & 1996 & 5.85 & 4.26 & 0.83 & 11 & 1.5 \\
\hline $\mathrm{PR}+\mathrm{DE}$ & 1999 & 10.18 & 6.96 & 0.91 & 15 & 1.5 \\
\hline
\end{tabular}


Table 2: Voting Support for Prime Minister, Likud and Labour in Selected Communities

(per cent)

\begin{tabular}{||l|c|c|c|c|c|c|c|c||}
\hline \multirow{2}{*}{} & \multicolumn{2}{|c|}{ Netanyahu } & Barak & Peres & \multicolumn{2}{c|}{ Likud } & \multicolumn{2}{c|}{ Labour* } \\
\cline { 2 - 9 } & $\mathbf{1 9 9 9}$ & $\mathbf{1 9 9 6}$ & $\mathbf{1 9 9 9}$ & $\mathbf{1 9 9 6}$ & $\mathbf{1 9 9 9}$ & $\mathbf{1 9 9 6}$ & $\mathbf{1 9 9 9}$ & $\mathbf{1 9 9 6}$ \\
\hline National Total & $\mathbf{4 3 . 9}$ & $\mathbf{5 0 . 5}$ & $\mathbf{5 6 . 1}$ & $\mathbf{4 9 . 5}$ & $\mathbf{1 4 . 1}$ & $\mathbf{2 5 . 8}$ & $\mathbf{2 0 . 3}$ & $\mathbf{2 7 . 5}$ \\
\hline Jewish Settlements & 48.3 & 55.6 & 51.5 & 44.3 & 15.4 & 27.4 & 21.6 & 27.7 \\
\hline Non-Jewish Settlements & 5.3 & 5.2 & 94.3 & 94.7 & 1.3 & 2.2 & 7.7 & 16.7 \\
\hline Druse Settlements & 20.6 & 21.3 & 79.3 & 78.6 & 7.9 & 11.7 & 21.7 & 40.5 \\
\hline Bedouin Settlements & 8.6 & 6.8 & 91.3 & 93.1 & 0.7 & 1.5 & 4.0 & 14.9 \\
\hline Bnei Brak & 88.7 & 88.9 & 11.2 & 11.0 & 6.5 & 11.1 & 4.4 & 6.6 \\
\hline Jerusalem & 64.5 & 69.9 & 35.4 & 30.0 & 15.2 & 25.6 & 14.1 & 16.3 \\
\hline Nazareth & 1.1 & 1.3 & 98.8 & 98.6 & 0.2 & 0.3 & 3.4 & 3.5 \\
\hline Nazareth Heights & 46.0 & 51.2 & 53.9 & 48.7 & 19.3 & 28.4 & 12.9 & 28.4 \\
\hline Tel Aviv & 35.6 & 44.8 & 64.2 & 55.1 & 15.4 & 26.6 & 27.4 & 33.9 \\
\hline Golan Heights & 41.4 & 49.7 & 58.5 & 50.2 & 9.2 & 16.3 & 23.3 & 31.2 \\
\hline Jews Beyond Green Line & 78.0 & 83.7 & 21.9 & 16.2 & 19.5 & 32.1 & 8.3 & 10.1 \\
\hline Kibbutzim & 6.8 & 10.0 & 93.1 & 89.9 & 1.8 & 3.1 & 50.5 & 54.8 \\
\hline Moshavim & 44.2 & 51.8 & 55.7 & 48.1 & 16.3 & 26.7 & 30.8 & 34.8 \\
\hline \hline
\end{tabular}

Source: IDI, Israel Democracy Institute web site at <www.idi.org.il>

* Labour run as One Israel in 1999 
Table 3: Electoral Performance of Selected Parties (1992-1999)

\begin{tabular}{|c|c|c|c|c|c|c|}
\hline \multirow[t]{2}{*}{ PARTY } & \multicolumn{2}{|c|}{1992} & \multicolumn{2}{|c|}{1996} & \multicolumn{2}{|c|}{1999} \\
\hline & $\%$ & seats & $\%$ & seats & $\%$ & seats \\
\hline Labour & 34.7 & 44 & 27.5 & 34 & 20.3 & 26 \\
\hline Likud & 24.9 & 32 & 25.8 & 32 & 14.1 & 19 \\
\hline Meretz & 9.6 & 12 & 7.5 & 9 & 7.6 & 10 \\
\hline Tsomet & 6.4 & 8 & \multicolumn{2}{|c|}{-} & 0.1 & - \\
\hline Y'Israel Be'aliyah & \multicolumn{2}{|c|}{-} & 5.8 & 7 & 5.1 & 6 \\
\hline Y'Israel Beiteinu & \multicolumn{2}{|c|}{-} & \multicolumn{2}{|l|}{0.0} & 2.6 & 4 \\
\hline Shinui & \multicolumn{2}{|c|}{-} & \multicolumn{2}{|c|}{-} & 5.0 & 6 \\
\hline Third Way & \multicolumn{2}{|c|}{-} & 3.3 & 4 & 0.7 & - \\
\hline The Centre Party & \multicolumn{2}{|c|}{-} & \multicolumn{2}{|c|}{ - } & 5.0 & 6 \\
\hline Shas & 4.9 & 6 & 8.7 & 10 & 13.0 & 17 \\
\hline National Religious Party NRP & 5.0 & 6 & 8.1 & 9 & 4.2 & 5 \\
\hline United Torah Judaism UTJ & 3.3 & 4 & 3.3 & 4 & 3.7 & $\frac{5}{5}$ \\
\hline United Arab List & \multicolumn{2}{|c|}{-} & 3.0 & 4 & 3.4 & 5 \\
\hline Hadash & 2.4 & 3 & 4.4 & 5 & 2.6 & 3 \\
\hline Balad & \multicolumn{2}{|c|}{-} & \multicolumn{2}{|c|}{-} & 1.9 & 2 \\
\hline Arab Democratic Party & 1.6 & 2 & \multicolumn{2}{|c|}{-} & \\
\hline
\end{tabular}


Figure 1: Decline of Major Parties and Proliferation of Middle-Sized Parties parties with 5 per cent and over)*

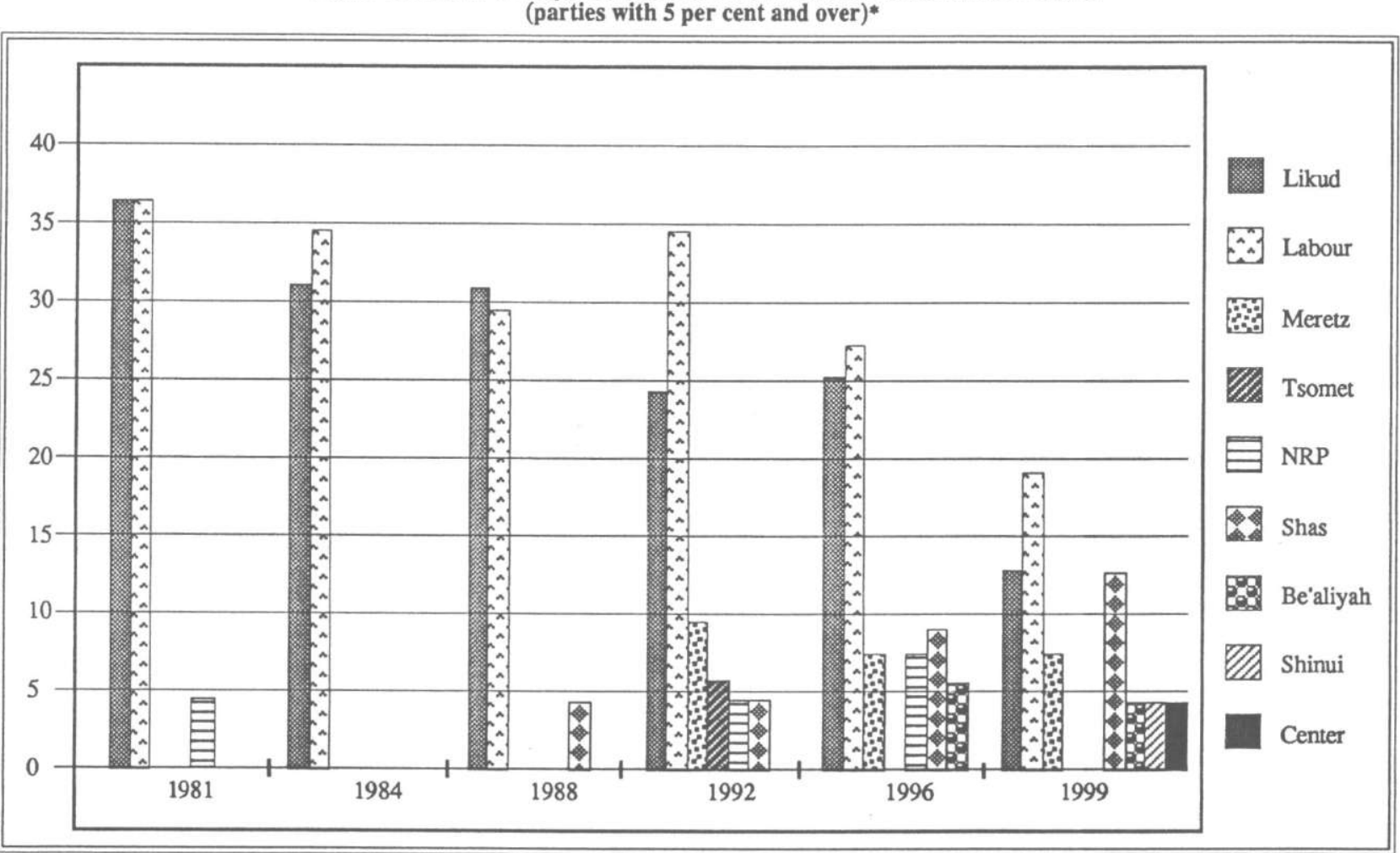

* 4.5 per cent and over rounded up to 5 per cent 